Биљана Б. Мишић*

Универзитет у Источном Сарајеву

Филозофски факултет Пале

Катедра за србистику

https://doi.org/10.18485/ai_zsjoski.2019.2.ch15

821.163.41.09-31 Драгић Л.

811.163.41'367.625

\title{
ГЛАГОЛИ КРЕТАҢА СА СЕКУНДАРНИМ ЗНАЧЕЊЕМ У РОМАНУ КУКАВИЧЈА ПИЛАД ЛАБУДА ДРАГИЋА
}

Глаголи кретања укључују просторну компоненту као примарну семантичку компоненту, тако да су, вјероватно, најфреквентнији тип глагола у сваком наративном тексту. За разлику од већине семантичких категорија глагола, глаголе кретања карактерише и особина метафоричности. У овоме раду управо ћемо се бавити анализом секундарних значења глагола кретања у роману Кукавичја ӣuлаg Лабуда Драгића.

Кључне ријечи: глаголи кретања, секундарно значење, правац кретања, адлативност, аблативност, перлативност.

\section{Уводне напомене}

Тема романа Кукавичја йилаg везана је за почетак 20. вијека, тачније за период Првог свјетског рата и непосредно након његовог завршетка. Враћајући се завичајном колориту Црне Горе, Драгић приповиједа о комитском покрету, који је настао послије формирања Краљевине Срба, Хрвата и Словенаца са циљем да

* bilja.misic@gmail.com 
најбруталнијим средствима покуша да организује побуну народа и да краља Николу врати на пријесто државе. О овоме роману писано је не само са књижевнокритичког, него и са језичког становишта. ${ }^{1}$ Сви истраживачи указивали су на богатство Драгићевог језика, чије се естетске вриједности препознају најприје у лексици (Бабић 2017: XXIV-XXV; Ковачевић 2017: 25-41; Милановић 2017: 73-81; Стојановић 2017: 13-23; Чутура 2017: 83-100). Роман Кукавичја йилаg отвара низ тема погодних за лингвистичку анализу, а ми ћемо се овом приликом бавити глаголима кретања са секундарним значењем.

У српском језику кретање се изражава различитим језичким средствима, прије свега, глаголима. Глаголи кретања обухватају све оне глаголе који значе помјерање, кретање неког објекта из једне тачке у простору у другу тачку у простору за неко вријеме. У ову су лексичко-семантичку групу глагола „укључени сви глаголи обједињени инваријантном семемом премјештање кога или чега у простору” (Ковачевић 2015: 61). Лингвисти који су истраживали глаголе кретања по правилу су анализирали различит број глагола дајући различите класификације. Истицано је да се при класификацији ових глагола мора имати у виду неколико фактора као што су: носилац кретања, брзина кретања, правац кретања, циљ кретања, техника кретања, зависност кретања од воље субјекта (Апресјан 1974: 252; Гак 1977: 155; Криле 1981: 14; Малетић 1988-1990: 238; Ковачевић 2015: 61). П. Пипер (2001: 95) наводи да се глаголи кретања у семантичком погледу дијеле на двије, по обиму, неједнаке групе. У већој групи сврстани су глаголи који значе кретање у средини која је основна средина човјековог кретања, а у другој, знатно

1 У часопису Узданица (2017) објављени су бројни радови, у којима се роман Кукавичја йилаg освјетљава како са књижевног тако и са језичко-стилског аспекта. 
мање бројној групи, убрајају се глаголи којима се означава кретање водом или ваздухом. С обзиром на то да је лексичко-семантичка група глагола кретања врло широка, па је њене границе тешко прецизно повући, јер велики број глагола у својој семантици садржи кретање, али се оно не фокусира као примарна значењска компонента - у овоме раду анализираћемо само секундарна значења глагола кретања. Под секундарним значењем подразумијевамо сва значења полисемичке структуре која су директно или индиректно изведена од примарног значења. А сва се нова значења једне лексеме, како наглашава Д. Гортан Премк (1997: 110), реализују „увек и само, у одређеној семантичкој позицији оној која се може опи-

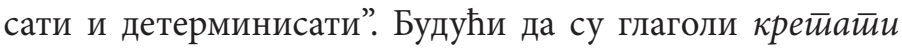
(ce), односно, кренуй и и ићи прототипи глагола кретања (Криле 1981: 13, Малетић 1988-1990: 238-240), у анализи најприје полазимо од ових глагола.

Секундарна значења ілаїола кренути и ићи

а) Кренуйи

у најширем смислу схваћена, основна компонента кретања садржана је у значењу глагола крейайи (се). Овај глагол заузима хијерархијски највише мјесто, с обзиром на то да није обиљежен компонентама које су релевантне за семантику (Малетић 1988-1990: 239). Основно значење глагола кренуши и је „поћи, упутити се” (Речник 2011: 573). Из корпуса издвајамо сљедећа секундарна значења:

a) Ако је кренула јагорчевина, брзо ће друго цвијеће $(32)^{2}$; Само да крене јагорчевина и писне каћун, да удари козалац и сријемуша (194).

б) Кад крену лучинске плиме и устану воде не завршавају се послови (117); Кад се Распоповић

2 Број у загради односи се на број странице извора чији су библиографски подаци дати на крају рада. 
појави с друштвом на старом коначишту, у Шћепан долу, код Станка Драшковића, из једног ипца крену препирка и свађа (141).

У примјерима под а) глагол кренуйи реализује значење 'почети расти, тјерати изданке', док се у примјерима под б) јавља значење 'почети, започети, отпочети'. Наведени примјери из обје групе показују да битан елемент који омогућава настајање секундарних значења јесте онај који се тиче започињања процеса кретања.

\section{б) $И \hbar u$}

Основна семантичка реализација глагола $и \hbar u$ у Речнику CJ (2011: 479) дефинисана је као „кретати се корачајући, ходати, пешачити”. У овој дефиницији налазе се семантички два битна елемента - један је кретање, а други 'правити кораке', односно 'ходати'. Полисемија глагола $u \hbar u$ је веома разграната, што потврђује велики број секундарних значења ,која се односе на најразличитије сегменте стварности а произлазе из његових семантичких обележја” (Вујовић 2010: 725). Један од разлога за изузетну семантичку разуђеност овог глагола јесте његова платисемичност. ${ }^{3}$ Наводимо сљедеће примјере:

а) Вазда је прољеће код нас ишло заједно са снијегом и набреклим пупољцима (16).

б) Од Цетиња су, опет, путеви ишли амо и грабили у њима хитри пјешаци, коњаници и перјаници (91).

3 У србистици термин йлайисемија уводи И. Грицкат (1967: 218-235). Ауторка истиче како „нема основа за претпоставку да би тај глагол морао некад значити само ход помоћу ногу, а да је казивање као 'иду дани' нека врста пренесености представе о ходу на персонифицирано 'дан'. Ићи је највероватније имало првобитно широко значење самоиницијативног или самониклог кретања" (Грицкат 1967: 224). 
Како се види, у примјеру а) глагол ићu има врло сложену семантику. С обзиром на то да семантику глагола условљава и семантика именице уз коју стоји, овдје глагол $u \hbar u$ има готово зеугмичко значење, будући да уз именице йрољеће и йуйољии значи 'долазити, стизати', а уз именицу снијеі има значење 'отићи'. Захваљујући немаркираности у погледу начина, брзине и правца кретања њиме се, као што уочавамо, секундарно могу означити различите врсте кретања. Тако у примјеру б) секундарно значење глагола uћu заснива се и на идеји кретања као простирања кроз простор. За разлику од претходног, у овом примјеру глагол ићu има значење: 'пружати се, водити', што је индицирано контекстом ситуације о којој се приповиједа.

Како се из примјера види, семантичка ширина глагола кретања представља погодно средство за њихову метафоричну употребу, мада су метафоризацији више подложни префигирани глаголи (Тошовић 1995: 128). Имајући у виду Тошовићево запажање, у наставку рада анализираћемо префигиране глаголе кретања који реализују секундарно значење.

\section{Префигирани глаголи кретања са секундарним значењем}

У српском језику префигираним глаголима кретања означава се 'усмјереност' / 'правац кретања'. С тим у вези, ова семантичка компонента послужиће нам као критеријум за класификацију примјера које ћемо сврстати на

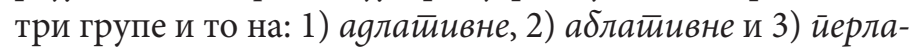
йивне префигиране глаголе. 'Усмјереност'/ 'правац кретања', као архисема, разлаже се „на три семе које према тој архисеми имају улогу диференцијалних сема, али према елементарним семама на које се могу разложити имају улогу архисема” (Ковачевић 2015: 62). 
1) Глаголи кретања адлативног усмјерења су они глаголи којима се означава приближавање неком оријентиру у простору. Адлативно усмјерено кретање у роману обиљежава глагол gоћи који се одређује као „идући, путујући или уопште крећући се стићи, доспети, приспети негде" (Речник 2011: 298). У основном значењу, дакле, овај глагол описује људско кретање са наглашеним завршним сегментом путовања, а из дефиниције глагола goћu јасно се види колико је овај глагол погодан за описивање метафоричког садржаја. То репрезентују сљедећи примјери који се тичу кретања у пренесеном смислу, као нпр:

a) Прољеће у наш крај gолази с лапавицом и студеном кишом и ријетким пробљесцима младог и бледуњавог сунца кроз облаке (15); Све нас испуњавало је то неком нејасном милином и чинило нам се да ће gоћи неко ново, срећно доба. (15); Прољеће, у инат свему, gолази (28).

б) Иза овога је gолазило неко једва примијетно, али блажено клонуће (128);

в) Кад мину Шваба и gође ослобођење и створи се велика нова држава, ево сад неки комити и њима се прикључио Крстов син (26);

г) Знали су гдје ће најбрже gоћи до вина и ракије, а онда би се напили и запјевали (191).

д) Баба данима gолази себи (27).

Како се види, код примјера из а) групе инваријантна семантичка компонента 'адлативност' индуктор је семантичке трансформације, што значи да је глагол gоћи са значењем 'настати, наступити' метонимијски употријебљен.

За разлику од ових примјера, у подлози секундарних значења из групе б), у којој глагол gоћи има значење 'појавити се, створити се, искрснути' и групе в) гдје се реализује значење 'доспјети у неко стање, околности, ситуацију', налази се метафорична дисперзија у којој апстрактне именице клонуће и ослобођене иницирају и 
омогућавају реализацију новог семантичког садржаја, тј. имају функцију семантичког детерминатора. ${ }^{4}$ Осим семантичког детерминатора, нужан услов за реализацију метафоричних значења представља и синтаксички детерминатор који, у неким случајевима, може бити унапријед задан. То потврђује примјер: Знали су гдје ће најбрже goћu до вина и ракије, а онда би се напили и запјевали (191), гдје глагол goћu само уз генитив са приједлогом go може реализовати значење 'набавити, прибавити (нешто), домоћи се (нечега)'. Посљедњи примјер: Баба данима gолази себи потпада под идиоматске изразе, тј. фразеологизме. У овој семантичкој позицији глагол goћu остварује значење 'опаметити се, уразумити се', а наведено значење доприноси сликовитом представљању психофизичког стања лика.

2) За разлику од адлативних глагола који означавају приближавање оријентиру, глаголи кретања аблативног усмјерења су они глаголи којима се означава удаљавање од неког оријентира у простору. У групи аблативних префигираних глагола издвајамо глагол оти $и ћ и$ који се дефинише као „напустити (неко место), удаљити се, уклонити се” (Речник 2011: 882). У корпусу смо забиљежили само један примјер за секундарно значење овог глагола: Јунаштво и слава оgоше на једну страну, Цар јунака на другу! (35).

Наведени примјер показује да је за реализацију секундарног значења глагола кључни фактор контекст, односно семантичка позиција у којој лексеме једна другој индукују семантички садржај. Овдје се актуализује значење 'прећи, прићи другој супротној страни' које омогућава инваријантна семантичка компонента 'усмјереност' ' правац кретања'.

4 О семантичком и синтаксичком детерминатору в. Гортан Премк (1997: 51-54). 
3) Перлативно усмјерено кретање у Драгићевом роману означава се глаголима $\bar{u} p e \hbar u$ и $\bar{u} р о ћ u$. Префикси üpe- и йро- су типични перлативни префикси, па глаголи $\bar{u} p e \hbar u$ и йроћи означавају кретање које се одвија у правцу прелажења неке путање. Примарно значење глагола йрећu одређује се као „идући премештајући се, превалити (какво растојање, какав простор)" (Речник 2011: 1014). Из корпуса издвајамо сљедећа секундарна значења:

a) Стога би се ласно могло закључити да је он йpeшао у њину вјеру, а не она у нашу (40);

б) Потом је тај глас йрелазио у цвилеж какав пуштају младо пруће и лиснике при сагоријевању на букари (20); Сјећање на гувно йрелазило је у сан, па се и он тулио (187); Миле Миљанић из Бањана пјевао је, а његова попијевка је неосјетно ирелазила у лелек, а лелек се, на тренутке, преобраћао у пјесму (213).

У примјеру: Стога би се ласно могло закључити да је он йрешао у њину вјеру, а не она у нашу, гдје глагол ūpeћu значи 'напустити један друштвени положај, занимање, идеологију и прихватити се чега другог', архисема „перлативност”, односно „прелажење” омогућава развитак новог семантичког садржаја. Будући да је архисема индуктор за асоцијације, ово значење је настало метонимијском дисперзијом, насупрот примјерима из групе б), гдје се секундарна реализација глагола йрећи 'промијенити се, постати друго' развија захваљујући диференцијалној семи, префиксу ӣре-, који подразумијева 'претварање, превођење из једног стања у друго'.

Глагол йроћи дефинише се као „идући преместити се с краја на крај неког простора” (Речник 2011: 1063). Секундарне семантичке реализације које смо забиљежили у корпусу су:

a) Башовића некако нагло йрође жеђ (129); Учинило се да га је трајно йрошла жеђ и да је с њега 
спао сав умор, и да му тијело прожима нестварна лакоћа, да би сад из једнога ипца могао на врх Дурмитора па опет назад, само да то неко од њега заиште (129);

б) Давно је иррошло то вријеме кад је вјерово у култ јунаштва и части (61); Прошле су већ двије недјеље како у Гаети борави чета „нове црногорске војске" (67); Ма не йрође ни неђеља дана, ево ти другије хајдука (28); Прошло је било више од четврт вијека, како Краљ примаше дарове од Штросмајера и од самога Папе, а послије свих тих дарова и ове савјете да се штампају зелени и бијели биљети (38).

У групи а) ироћи има значење 'престати', док код примјера б) његово значење је 'минути, завршити се'. Ова су секундарна значења настала метафоричком транспозицијом семе нижег ранга, тј. префикса йро- , који у значењу 'престати' означава довршену радњу, док се код значења 'минути, завршити се' односи на радњу која има за посљедицу какво пролажење.

И да закључимо. Глаголи кретања су фреквентна језичка средства у Драгићевом роману, а њихова честа употреба може се објаснити богатим семантичко-стилистичким потенцијалом, прије свега, могућношћу широке употребе у пренесеном значењу. Услов за реализацију свих анализираних секундарних значења је семантичка позиција са семантичким и синтаксичким детерминатором, без обзира на то да ли су она индукована метонимијом или метафором. Интересантно је да се у роману ови глаголи кретања јављају у говору наратора, и то, по правилу, у дескриптивним микродискурсима, као нпр. кренула јаїорчевина, крену лучинске ӣлиме, ишло иррољеће, gолази иррољеће, итд. Друкчије речено, глаголи кретања са секундарним значењем своју функционалну вриједност 
показују када су посриједи контексти у којима се тежи постизању сликовитости при дескрипцији природе, која је „непрестано присутни слој у позадини приказаних догађаја и судбина" (Бабић 2017: ХХ).

\section{Извори}

Драгић 2017: Л. Драгић, Кукавичја ӣuлаg, Београд: Српска књижевна задруга, Подгорица: Књижевна задруга српског националног савјета.

\section{Литература}

Апресјан 1974: Ю. Д. Апресян, Лексическая семанииика.

Синонимические среgсиива языка. Москва: Издательство „Наука”.

Бабић 2017: Д. Бабић, Горки талог историје, предговор књизи Кукавичја йилаg, Београд: Српска књижевна задруга, Подгорица: Књижевна задруга српског националног савјета, XVII-XXV.

Вујовић 2010: D. Vujović, Semantika glagola ići u Andrićevim pripovetkama iz Austrougarskog perioda, Austrougarski period u životu i djelu Iva Andrića, Beograd, 723-730.

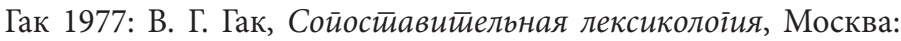
Издательство „Международные отношения”.

Гортан Премк 1997: Д. Гортан Премк, Полисемија и оріанизаиија лексичкоі сисиемма у срӣском језику, Београд: Институт за српски језик САНУ.

Грицкат 1967: И. Грицкат, Стилске фигуре у светлу језичких анализа, Наш језик, XVI/ 4, Београд, 217-235.

Ковачевић 2015: М. Ковачевић, Префиксација и њен утицај на форму и семантику синтагме, Кроз синйаіме и реченице, Београд: Јасен, 59-70. 
Ковачевић 2017: М. Ковачевић, Специфични поступци пререгистрације у роману Кукавичја йилаg Лабуда Драгића, Уздании, ХІ XIV/ 2, Јагодина, 25-41.

Криле 1981: I. Krile, O pojmu kretanja u hrvatskom književnom jeziku, Jezik, 29, Zagreb, 13-19.

Малетић 1988-1990: Н. Малетић, Из глаголске семантике: глаголи кретања у српскохрватском језику, Прилози йроучавату језика, 24-26, Нови Сад, 237-249.

Милановић 2017: А. Милановић, Лексички слојеви у роману Кукавичја йилаg Лабуда Драгића, Узgаница, XIV/ 2, Јагодина, 73-81.

Пипер 2001: P. Piper, Jezik i prostor, Beograd: Biblioteka XX vek.

Стојановић 2017: J. Стојановић, Језичко-стилска средства која доприносе вјеродостојности казивања у роману Кукавичја йuлаg Лабуда Драгића, Узgании, Х, XIV/ 2, Јагодина, 13-23.

Тошовић 1995: В. Tošović, Stilistika glagola, Wuppertal: Lindenblatt.

Речник 2011: Речник срӣскоїа језика, Нови Сад: Матица српска. Чутура 2017: И. Чутура, Значење и стилистика прилога у роману Кукавичја йилаg Лабуда Драгића, Узgании, XIV/ 2, Јагодина, 83-100. 
Biljana Mišić

\section{BEWEGUNGSVERBEN MIT SEKUNDÄRER BEDUTUNG IN DEM ROMAN KUKAVIČJA PILAD VON LABUD DRAGIĆ}

Die Bewegung der Verben impliziert eine räumliche Komponente als eine primäre Komponente diese Verben, so dass sie die häufigsten Verbtypen in jedem narrativen Text sind. Im Unterschied zu dem meisten semantischen Verbkategorien, bezeichnet die Bewegugsverben auch eine gewisse Metaphorik. In dieser Arbeit haben wir uns mit den sekundären Bedeutung der Bewegungsverben in dem Roman "Kukavicija Pilad" beschäftigt. Die Analyse hat gezeigt, dass die Verben mit der sekundären Bedeutung ihren funktionelen Wert in den Kontexten bekommen, in denen men versucht eine malerische Audruckskraft zu erzielen, d.h ein Präzision und Vielfalt der Beschreibung.

Schlüsselwörter: Bewegungsverben, sekundären Bedeutung, Bewegungsrichtung, Adlativität, Ablativiätet, Perlativität. 